
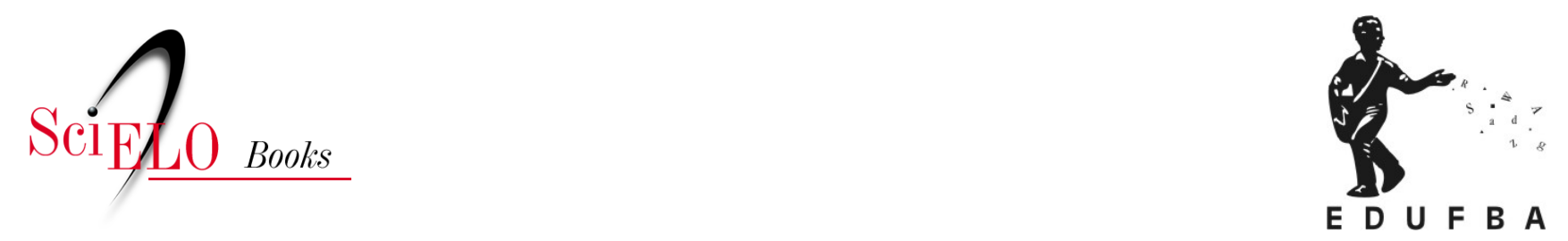

\title{
Prefácio \\ Movimentos e conjunturas da cidade-atração em três capitais brasileiras
}

\author{
Ana Fernandes
}

\section{SciELO Books / SciELO Livros / SciELO Libros}

FERNANDES, A. Prefácio: Movimentos e conjunturas da cidade-atração em três capitais brasileiras. In: SANT'ANNA, M. A cidade-atração: a norma de preservação de áreas centrais no Brasil dos anos 1990 [online]. Salvador: EDUFBA-PPG-AU FAUFBA, 2017, pp. 13-16. ISBN: 978-85-232-1871-3. https://doi.org/10.7476/9788523218713.0001.

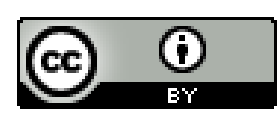

All the contents of this work, except where otherwise noted, is licensed under a Creative Commons Attribution 4.0 International license.

Todo o conteúdo deste trabalho, exceto quando houver ressalva, é publicado sob a licença Creative Commons Atribição 4.0.

Todo el contenido de esta obra, excepto donde se indique lo contrario, está bajo licencia de la licencia Creative Commons Reconocimento 4.0. 


\section{Prefácio: Movimentos e conjunturas da cidade-atração em três capitais brasileiras}

O século XXI, em suas duas primeiras décadas, reafirma o papel âncora das cidades, com suas exacerbadas hierarquias e desigualdades, nos processos globais de reprodução, centralização e rentabilização de capitais associados em sua forma financeira e corporativa. Em movimentos de expansão e retração, crescimento e crise, o espaço urbano vem sendo objeto de investimentos volumosos, guiados, no entanto, por lógicas que, embora felizmente múltiplas, evidenciam-se como eminentemente privadas e de regulação pública cada vez mais frágil e permissiva. A produção sequenciada de outorgas e de novos instrumentos legais que validam a ação privada na definição de políticas é marca contundente desse processo. As Manifestações de Interesse Privado (MIPs) são exemplares a esse respeito.

Nesses processos de intervenção imperial sobre as cidades, merece ser ressaltado o protagonismo que organismos e corporações internacionais ocupam tanto no financiamento de programas quanto na sua definição e implementação. Uma espécie de política urbana às avessas, vinculada mais à circulação e rentabilização de recursos econômicos crescentemente tornados "imateriais", 
pela sua redução ao valor de troca e suas possibilidades de especulação global, do que propriamente a horizontes de mudanças socialmente relevantes no âmbito das cidades e dos territórios.

Subjugado pelas lógicas restritas e vorazes do mercado, o processo de produção de novos empreendimentos passa a ser espelho também da produção de obsolescência urbana. Ou seja, a lógica perversa dos processos recentes de urbanização do território, sua dispersão, difusão e produção em escala industrial, têm levado, de forma crescente, à produção precoce de espaços esvaziados, particularmente em áreas centrais. São assim gerados, ao mesmo tempo, espaços novos - muitos avançando em territórios rurais às franjas da urbanização - e espaços centrais em crise, crescentemente degradados. Trata-se da produção ampliada de vazios construídos, enorme desperdício de território social e urbano coletivamente produzido.

Não por acaso, nas cidades brasileiras, o número de unidades vazias iguala, ou mesmo supera, o déficit habitacional existente e, raras exceções à parte, os centros urbanos tradicionais vivem uma crise crescente de reprodução, com processo de despovoamento que tarda a ser revertido.

A questão dos centros vai então progressivamente se constituir em problema público no Brasil e, a partir dos anos 1990, políticas de governo, bem como estratégias privadas e sociais, sob diferentes perspectivas, vão buscar equacionar e enfrentar essa questão.

A cidade-atração, objeto do presente livro, busca analisar esse processo a partir das questões relativas ao patrimônio em 3 cidades brasileiras: Salvador, Rio de Janeiro e São Paulo. Trata-se de compreender os sentidos subjacentes à proliferação, banalização e funcionalização da ideia e da prática patrimoniais que invadiram as cidades - no mundo e no Brasil - e se intensificaram a partir da última década do século XX, sobretudo concentradas nas áreas centrais das cidades.

Encadeando com a reflexão teórica desenvolvida em seu trabalho anterior, Da Cidade-Monumento à Cidade-Documento, obra publicada em 2014, Márcia Sant’Anna compreende essa generalização da lógica patrimonial como a plenitude de sua vigência enquanto dispositivo de poder, agora alimentado essencialmente por sua função econômica. Assim, ao alegre consumo da urbanidade contemporânea, festejado por aparatos midiáticos, governamentais e corporativos, contrapõe-se aqui uma análise rigorosa de vínculos, lógicas, articulações e hierarquias 
que moldam a compreensão de uma forma dominante de produzir patrimônio - a cidade-atração -, cada vez mais distanciada de sentidos sociais e culturais mais amplos e inclusivos.

Para realizar seu intento, a autora se utiliza da conceituação foucaultiana de dispositivos e de sua tradução/explicitação em normas, assim como da formulação deleuziana dos regimes de visibilidade. A isso se soma tanto um percurso cuidadoso sobre a literatura que trata dos temas do patrimônio e da dinâmica urbana quanto um extenso e rico trabalho de levantamento e sistematização de dados sobre as três cidades escolhidas para análise e sobre os programas nacionais de financiamento a ações de preservação/requalificação.

A cidade-atração, a meu ver, pode ser entendida como uma relevante contribuição ao estudo das políticas de preservação, assim como dos processos patrimoniais em curso nas metrópoles brasileiras, teórica e empiricamente falando. Isso é tão mais importante quanto se generaliza atualmente uma certa idealização e extensão da ideia de patrimônio, que tende a substituir in tótum a complexidade dos embates sociopolíticos na produção do espaço.

Assim, o fenômeno da patrimonialização dos centros urbanos aqui descrito nos coloca frente a possibilidades sensivelmente distintas para o destino de nossas centralidades e cidades. Por um lado, a relação cada vez mais íntima que se tece entre a ideia de patrimônio e as possibilidades de reproposição/requalificação/renovação de espaços nas cidades, tensionados por relações verticais de forças, marcadas pela lógica do negócio, fortemente ancorada em articulações restritas entre o poder público e o privado. Por outro, através da associação e sincronia entre ativismos sociais de diversas ordens, um tensionamento crescente do patrimônio enquanto esfera da construção do direito à cidade, por meio de movimentos de contestação da ordem hegemônica e de defesa de uma partilha mais horizontalizada da cidade e dos seus bens e espaços.

Em Salvador, por exemplo, a lógica patrimonial redesenha continuamente limites entre o público, o coletivo e o privado, com forte protagonismo do último. A $7^{a}$ etapa do Pelourinho, o Centro Antigo, a borda da Baía de Todos os Santos sintetizam com clareza essa ambiguidade da questão patrimonial e seu desdobramento em política pública, agrupando ou desconhecendo setores intelectuais, sociais, políticos e econômicos completamente diversos num ou noutro caso. 
Ao mesmo tempo, fissuras e cisões gritantes se apresentam em torno das definições, significados e usos a serem atribuídos às heranças e processos culturais (i)materiais, constituindo frentes de batalha significativas na luta pelo espaço. As mobilizações crescentes em torno do centro de Salvador ou as comunidades de memória, presentes em diversos bairros soteropolitanos, articuladas e incentivadas por coletivos de diferentes tipos de organização política e cidadã, parecem concentrar esperanças de disrupção na norma e no dispositivo.

O processo aponta para a possibilidade de uma nova conjunção de linhas de força e de interesse coletivo, ampliando o leque de opções na construção de políticas públicas que possam dar conta da confluência entre patrimônio, preservação e urbanismo, que enriqueçam social e culturalmente a cidade brasileira em sua multiplicidade e complexidade.

A inquietação intelectual da autora, seu rigor conceitual e sua capacidade de compreensão dos processos vigentes na conformação e desdobramentos de seu objeto de análise nos conduzem por percursos que revelam de forma agradável e inteligente as hegemonias e os meandros da cidade-atração.

Sem dúvida, uma leitura que nos oferece campos estimulantes para refletir, explorar e propor...

\section{Ana Fernandes}

Salvador, 07 de maio de 2017 